\title{
Acute mitral valve obstruction during infective endocarditis
}

\author{
RICHARD PRASQUIER, CLAUDE GIBERT, SERGE WITCHITZ, PAUL VALERE, \\ PHILIPPE BEAUFILS, FRANCOIS VACHON
}

\section{Summary and conclusions}

Five patients were found during surgery or at necropsy to have the mitral valve orifice obstructed by vegetations. They had had unexplained severe and recurrent episodes of acute febrile pulmonary oedema, and four had few cardiac ausculatory findings. Three patients died suddenly and unexpectedly; the other two were operated on and survived.

In view of its ominous prognosis, acute mitral valve obstruction should be considered in patients whose pulmonary symptoms are compatible with endocarditis and are not adequately explained by the findings on examination of the heart. The condition, which should be confirmed by echocardiography, requires emergency surgery.

\section{Introduction}

Haemodynamic complications of bacterial endocarditis usually result from valvular destruction. A bulky vegetation, however, may cause obstruction of the mitral valve, ${ }^{1}$ and our finding such obstruction in five patients has enabled us to define the clinical features of this severe complication of endocarditis.

\section{Case reports}

Case 1-A 41-year-old man with no history of cardiac disease had had a low-grade fever for two weeks, for which he had received oral ampicillin $(3 \mathrm{~g} / \mathrm{d})$ for four days. He was admitted in acute respiratory distress with fever $\left(39.5^{\circ} \mathrm{C}\right)$ and severe hypoxaemia but no sputum production; no heart murmur was elicited. He had a tracheostomy and mechanical ventilation and was given intravenous ampicillin $(8 \mathrm{~g} / \mathrm{d})$ and intramuscular gentamicin $(180 \mathrm{mg} / \mathrm{d})$. Eight blood cultures were sterile. He improved, his temperature returned to normal, and he was weaned off the respirator. Auscultation then disclosed a loud $S_{1}$, an apical $1 / 6$ systolic murmur and a $2 / 6$ diastolic rumble. After being symptom-free for two weeks but continuing on antibiotics he developed acute severe pulmonary oedema. After diuretic treatment his pulmonary wedge pressure was $20 \mathrm{~mm} \mathrm{Hg}$ without a conspicuous $\mathrm{V}$ wave. At operation to replace the mitral valve on the same day, the mitral orifice was found to be obstructed by a bulky vegetation in which Gram-positive cocci were found. A postoperative blood culture grew a D streptococcus. He recovered haemodynamically but died of pseudomonas mediastinitis 20 days after surgery. At necropsy the prosthesis showed no sign of dysfunction.

Clinique de Réanimation Médicale, Hôpital Claude-Bernard, Université de Paris VII

RICHARD PRASQUIER, MD, chef de clinique assistant (present address: Service de Cardiologie, Hôpital Beaujon, Université de Paris VII) CLAUDE GIBERT, MD, professeur agrégé SERGE WITCHITZ, MD, professeur agrégé FRANCOIS VACHON, MD, professeur

Service de Cardiologie, Hôpital Bichat, Université de Paris VII PAUL VALERE, MD, professeur agrégé

Clinique Cardiologique, Hôpital Lariboisière, Université de Paris VII PHILIPPE BEAUFILS, MD, chef de clinique assistant
Case 2-A 16-year-old boy, who had had a mitral commissurotomy five years earlier and was still having penicillin, had had a fever of $40^{\circ} \mathrm{C}$ for a month, though blood cultures were sterile. He was admitted in acute respiratory distress; findings on cardiac auscultation were normal; pulmonary wedge pressure was $16 \mathrm{~mm} \mathrm{Hg}$ and the cardiac index $31 / \mathrm{mn} / \mathrm{m}^{2}$. His condition improved rapidly, but three days later he had a further resolving episode of respiratory distress and died suddenly the next day. At necropsy large vegetations on the anterior leaflet, with Gram-positive cocci, were found obstructing the mitral orifice.

Case 3-A 51-year-old woman with no history of cardiac disease had a catheter-induced Staphylococcus aureus septicaemia after a cholecystectomy. She had had methicillin for two months, and during this time developed cerebral embolism, which resolved satisfactorily. She was then transferred to our unit with persisting septicaemia, a $3 / 6$ pansystolic apical murmur, and increasingly severe pulmonary oedema. The capillary wedge pressure was $14 \mathrm{~mm} \mathrm{Hg}$, with a $\mathrm{V}$ wave of $30 \mathrm{~mm} \mathrm{Hg}$ and a cardiac index of $2.81 / \mathrm{mn} / \mathrm{m}^{2}$. At operation to replace the mitral valve by a Björk prosthesis the mitral orifice was found to be almost completely obstructed by vegetations. The patient made an uneventful recovery.

Case 4-A 42-year-old patient, who had had rheumatic mitral valve disease of undefined severity, developed an acute respiratory distress syndrome with fever $\left(40^{\circ} \mathrm{C}\right)$ one day after a moderate injury to the chest. Blood cultures were sterile (he had been given oral spiramycin two days before), and cardiac examination showed no abnormality. He received penicillin $\mathrm{G}(50 \mathrm{MU} / \mathrm{d})$ and streptomycin ( $1 \mathrm{~g} / \mathrm{d}$ ) and his condition improved, but underwent two further episodes of acute respiratory distress associated with oliguric renal failure. On transfer to our unit his pulmonary symptoms improved rapidly; clinical examination showed splenomegaly, septic retinitis, a loud $S_{1}$, and a $1 / 6$ apical systolic murmur. His pulmonary artery pressure was $65 / 25 \mathrm{~mm} \mathrm{Hg}$ (no wedge pressure being obtainable). No organism was recovered on blood culture. Penicillin and streptomycin were continued, with peritoneal dialysis. Ten days after his admission he had an unexpected cardiac arrest. At necropsy his mitral valve orifice was found to be almost completely obstructed by a vegetation (fig 1) that contained Gram-positive cocci.

Case 5-A 23-year-old woman with no history of cardiac disease had been sent home from Gabon because of prolonged febrile bilateral pulmonary disease with radiological features of pulmonary oedema. Cardiac auscultation showed a faint $1 / 6$ apical systolic murmur. Echocardiography the day after admission produced abnormal echoes behind the anterior leaflet of the mitral valve (fig 2). An hour later she had a sudden cardiac arrest and was resuscitated. Cardiac catheterisation showed a mean pulmonary wedge pressure of $30 \mathrm{~mm}$ $\mathrm{Hg}$ with a cardiac index of $2 \cdot 11 / \mathrm{mn} / \mathrm{m}^{2}$. She remained unresponsive to treatment and died. At necropsy vegetations were found to fill the mitral orifice.

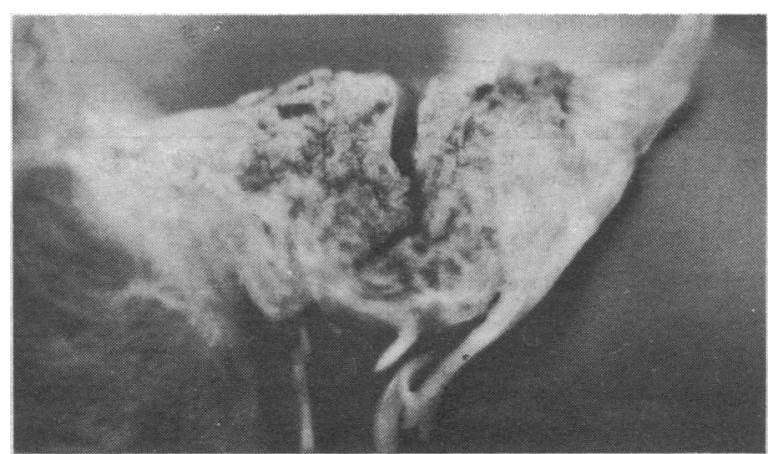

FIG 1-Case 4: Longitudinal section of mitral valve showing the severity of obstruction caused by the vegetation. 


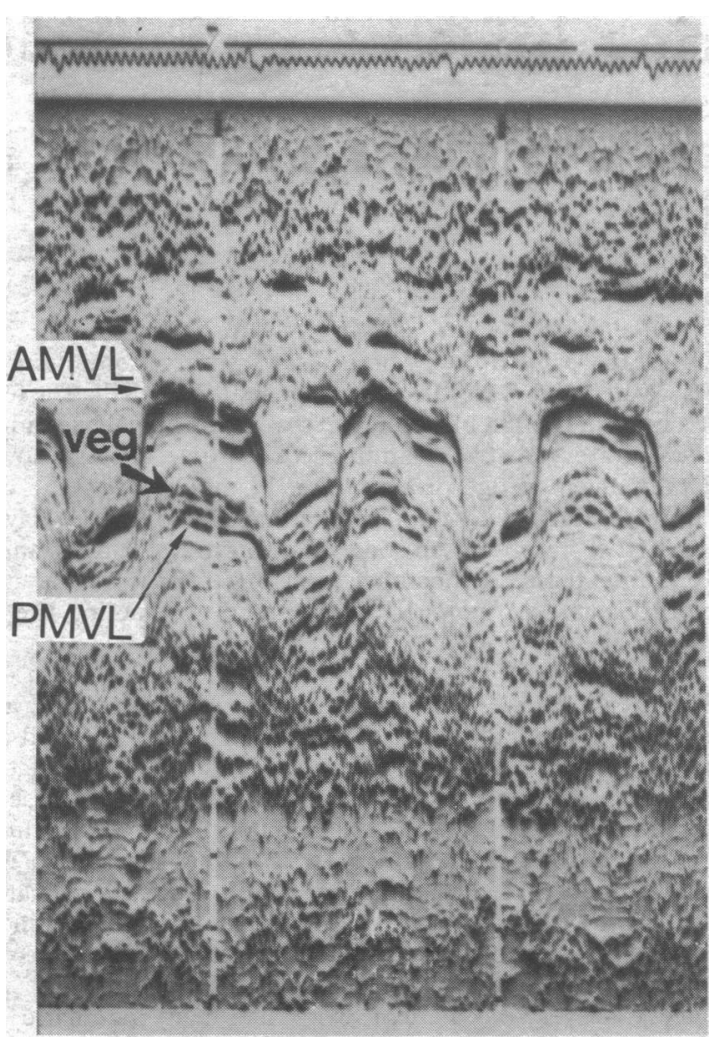

FIG 2-Case 5: Echocardiogram showing abnormal echoes behind the mitral valve.

AMVL = anterior mitral valve leaflet $P M V L=$ posterior mitral valave leaflet; veg $=$ vegetations.

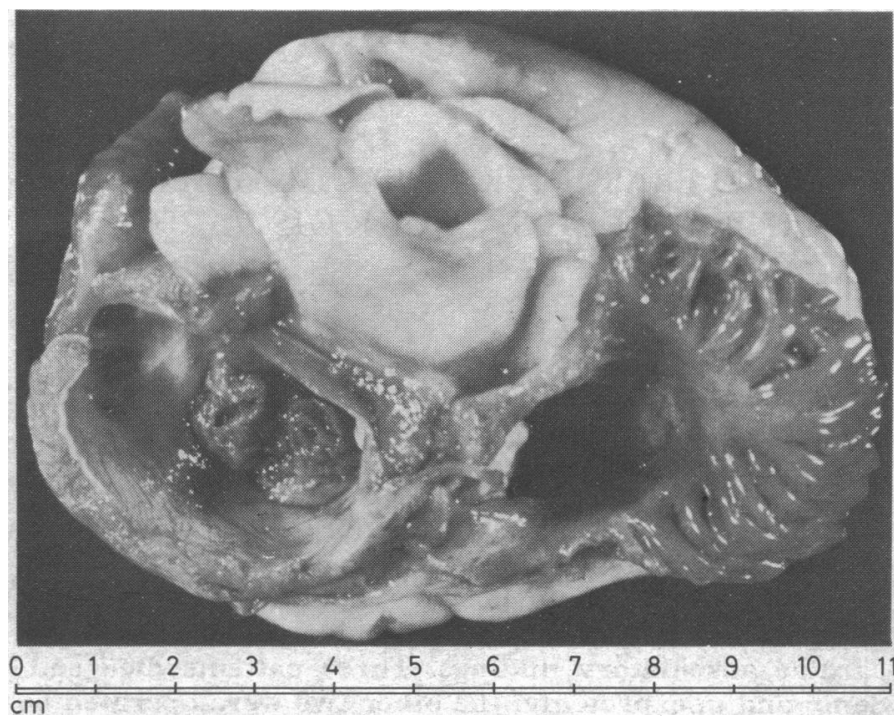

FIG 3-Case 5: Transverse section through the mitral valve (left) showing obstruction by a large vegetation.

\section{Discussion}

Certain clinical features were common to our five patients (table I) and, to a lesser extent, to patients in other reports of mitral valve obstruction during infectious endocarditis (table II). Four of our patients were admitted because of recurrent episodes of acute, febrile respiratory distress without clear auscultatory evidence of valvular disease; cardiac murmurs, when heard, were faint even after the pulmonary symptoms had receded; and

TABLE I-Clinical features of patients in present series

\begin{tabular}{|c|c|c|c|c|c|c|c|c|}
\hline $\begin{array}{l}\text { Case } \\
\text { No }\end{array}$ & $\begin{array}{c}\text { Previous heart } \\
\text { disease }\end{array}$ & $\begin{array}{c}\text { Previous } \\
\text { antibiotic } \\
\text { therapy }\end{array}$ & $\begin{array}{l}\text { Blood } \\
\text { cultures }\end{array}$ & Bacteria & $\begin{array}{l}\text { Duration of } \\
\text { symptoms } \\
\text { before } \\
\text { admission }\end{array}$ & Cause of admission & $\begin{array}{l}\text { Clinical cardiac } \\
\text { findings on admission }\end{array}$ & Clinical course \\
\hline 1 & No & Yes & - & $\begin{array}{r}\text { D streptococcus } \\
\text { (postoperative } \\
\text { blood culture) }\end{array}$ & 2 weeks & $\begin{array}{l}\text { Acute respiratory } \\
\text { distress } \\
\text { Fever }\end{array}$ & None & $\begin{array}{l}\text { Recurrent pulmonary } \\
\text { oedema; emergency } \\
\text { surgery; } \\
\text { mediastinitis; death }\end{array}$ \\
\hline 2 & $\begin{array}{l}\text { Mitral } \\
\text { commissurotomy }\end{array}$ & Yes & - & $\begin{array}{l}\text { Gram-positive cocci } \\
\text { (pathology) }\end{array}$ & 6 weeks & $\begin{array}{l}\text { Acute respiratory } \\
\text { distress } \\
\text { Fever }\end{array}$ & None & $\begin{array}{l}\text { Recurrent pulmonary } \\
\text { oedema; sudden } \\
\text { death }\end{array}$ \\
\hline 3 & No & Yes & + & Staph aureus & 5 weeks & $\begin{array}{l}\text { Pulmonary oedema } \\
\text { Persisting septicaemia }\end{array}$ & $\begin{array}{l}\text { 3/6 apical holosystolic } \\
\text { murmur }\end{array}$ & $\begin{array}{l}\text { Pulmonary oedema; } \\
\text { valve replacement; } \\
\text { recovery }\end{array}$ \\
\hline 4 & $\begin{array}{l}\text { Rheumatic mitral } \\
\text { valve disease }\end{array}$ & Yes & - & $\begin{array}{c}\text { Gram-positive cocci } \\
\text { (pathology) }\end{array}$ & 2 weeks & $\begin{array}{l}\text { Acute respiratory } \\
\text { distress } \\
\text { Fever }\end{array}$ & $\begin{array}{l}\text { 1/6 apical systolic } \\
\text { murmur }\end{array}$ & $\begin{array}{l}\text { Recurrent pulmonary } \\
\text { oedema; sudden } \\
\text { death }\end{array}$ \\
\hline 5 & Unknown & Yes & - & $\begin{array}{l}\text { Gram-positive cocci } \\
\text { (pathology) }\end{array}$ & 6 weeks & $\begin{array}{l}\text { Subacute respiratory } \\
\text { distress } \\
\text { Fever }\end{array}$ & $\begin{array}{l}\text { 1/6 apical systolic } \\
\text { murmur }\end{array}$ & Sudden death \\
\hline
\end{tabular}

TABLE II-Clinical features of previously reported patients

\begin{tabular}{|c|c|c|c|c|c|c|c|}
\hline & $\begin{array}{c}\text { Previous heart } \\
\text { disease }\end{array}$ & $\begin{array}{l}\text { Blood } \\
\text { cultures }\end{array}$ & Bacteria & $\begin{array}{l}\text { Duration of } \\
\text { symptoms }\end{array}$ & $\begin{array}{l}\text { Major clinical } \\
\text { cardiac findings }\end{array}$ & Clinical course & Outcome \\
\hline Reeve $e t a l^{1}$ & $\begin{array}{l}\text { Rheumatic heart } \\
\text { disease }\end{array}$ & + & Staph aureus & 10 days & None & $\begin{array}{l}\text { Increasing dyspnoea } \\
\text { Renal failure }\end{array}$ & $\begin{array}{l}\text { Ventricular fibrillation } \\
\text { (9th day); } \\
\text { resuscitated } \\
\text { Sudden death } \\
\text { (10th day) }\end{array}$ \\
\hline Matula et $a l^{2}$ & Mitral stenosis & + & Staph aureus & 8 weeks & $\begin{array}{l}\text { Apical diastolic } \\
\text { rumble (previously } \\
\text { known) }\end{array}$ & $\begin{array}{l}\text { Increasing dyspnoea } \\
\text { No regurgitant } \\
\text { murmur }\end{array}$ & $\begin{array}{l}\text { Surgery: mild mitral } \\
\text { stenosis; large } \\
\text { occluding } \\
\text { vegetation } \\
\text { Recovery }\end{array}$ \\
\hline Roberts et $\mathrm{al}^{\mathrm{s}}$ & $\begin{array}{l}\text { Rheumatic heart } \\
\text { disease }\end{array}$ & + & B streptococcus & 4 weeks & $\begin{array}{l}\text { Short apical diastolic } \\
\text { rumble } \\
\text { 3/6 apical holosystolic } \\
\text { murmur }\end{array}$ & Not reported & $\begin{array}{l}\text { Intracerebral } \\
\text { haemorrhage } \\
\text { Death }\end{array}$ \\
\hline
\end{tabular}


the severity of the clinical symptoms could not be adequately explained by valvular regurgitation, of which there was little evidence on examination of the heart. Blood cultures usually remained sterile, presumably because of inappropriate antibiotic treatment or the limited infectiveness of the organisms present, or both.

A striking feature in three patients (cases 1, 2, and 4) was the acute, severe, and rapidly resolving but recurrent episodes of pulmonary oedema. Possibly these were caused by sudden blocking of the orifice by vegetation-this was indeed shown echocardiographically in one patient (case 4). Other patients (cases 3 and 5 and those reported by Reeve et $a^{1}$ and Matula et $a l^{2}$ ) had more progressive pulmonary oedema, suggesting increasing mitral stenosis. In our experience both types of pulmonary oedema are uncommon in patients with isolated mitral valve regurgitation during bacterial endocarditis.

Those of our patients who did not have mitral valve replacement (cases 2, 4, and 5) and the patient of Reeve and his colleagues $^{1}$ had a sudden cardiac arrest. Mitral valve vegetations cause obstruction just as catastrophic as an atrial tumour or a ball thrombus, and hence once the doctor suspects mitral valve obstruction he should confirm the diagnosis promptly and ensure that the patient is rapidly operated on.

Accurate diagnosis is vital. Right heart catheterisation showed a raised pulmonary wedge pressure without a striking $\mathrm{V}$ wave, but was nevertheless of little value in assessing the severity of the haemodynamic disturbance: pressures may be very high because of rheumatic valve disease (case 4) or only moderately increased because the obstruction is intermittent. Echocardiography is the only method of detecting valvular vegetations directly: bulky vegetations such as occurred in these patients are unlikely to be missed. The technique has only a limited sensitivity, however, in mitral valve endocarditis. ${ }^{45}$ Linear echoes behind the mitral valve should not be confused with atrial myxoma $^{6}$; fungal, ${ }^{7}$ marantic, ${ }^{8}$ or granulomatous ${ }^{9}$ obstruction; or thrombus.

Hence whenever pulmonary oedema occurs in a patient with fever, haemodynamic oedema resulting from bacterial endocarditis should be suspected routinely even if the findings on cardiac auscultation are normal. A viral origin is unlikely if fever continues for more than a week. Cardiac catheterisation may not confirm the diagnosis and echocardiography should be used. When this gives abnormal echoes behind the mitral valve in a patient with the typical history and other features, emergency surgery should be carried out because of the risk of sudden death.

We thank Professor P Soyer, Professor E Hazan, Dr J P Bex, and Dr Y Leconte, who operated on our patients, and Dr C Bouton who performed the necropsies.

\section{References}

${ }^{1}$ Reeve, R, et al, fournal of the American Medical Association, 1974, 228, 75 2 Matula, G, et al, fournal of the American Medical Association, 1975, 233. 58.

${ }^{3}$ Roberts, W C, et al, Circulation, 1967, 36, 449.

4 Roy, P, et al, Circulation, 1976, 53, 474.

5 Wann, P, et al, New England fournal of Medicine, 1976, 295, 135

- Hirschfeld, D S, and Emilson, B B, Western fournal of Medicine, 1976, 124, 419.

7 Pasternak, R C, et al, British Heart fournal, 1976, 38, 1209.

${ }^{8}$ Estevez, C M, and Corya, B C, Chest, 1976, 69, 801.

${ }^{9}$ Fitchett, D H, and Oakley, C M, British Heart fournal, 1976, 38, 316.

\title{
Study of 8-year-old children with a history of respiratory syncytial virus bronchiolitis in infancy
}

\author{
D G SIMS, M A P S DOWNHAM, P S GARDNER, J K G WEBB, D WEIGHTMAN
}

British Medical fournal, 1978, 1, 11-14

\section{Summary and conclusions}

Thirty-five children known to have had respiratory syncytial virus bronchiolitis in infancy were examined at the age of 8 and their respiratory function tested. The results were compared with those in 35 controls matched for age, sex, and social class.

Although 18 of the children who had had bronchiolitis in infancy had experienced subsequent episodes of wheezing, these were neither severe nor frequent in most cases and had apparently ceased by the age of 8 . Nevertheless, the mean exercise bronchial lability of the children who had had bronchiolitis was significantly higher than that of the control children and the mean peak expiratory flow rate at rest significantly lower.

University of Newcastle upon Tyne, Newcastle upon Tyne D G SIMS, MB, MRCP, senior research associate in child health and virology $M$ A P S DOWNHAM, MRCP, DCH, senior lecturer in child health $P$ S GARDNER, MD, DIPBACT, professor of clinical virology J K G WEBB, MA, FRCP, professor of child health D WEIGHTMAN, assistant in medical statistics
Atopy, assessed by family and personal history alone, did not seem to be related to either bronchiolitis or wheezing episodes after bronchiolitis. The parents of the children who had had bronchiolitis smoked significantly more cigarettes during the infant's first year of life than those of the control children.

The results suggest that bronchiolitis and childhood asthma are not closely related. Bronchial hyperreactivity might be inherited independently of atopy, but environmental factors seem the most likely link between severe respiratory infection in infancy and chronic or recurrent respiratory illness in adult life.

\section{Introduction}

Does lower respiratory tract infection in infancy increase the risk of recurrent or chronic respiratory disease in later life? Difficult though this question is the answer may provide important new incentives for preventing and managing severe respiratory illness at all ages, and in recent years relevant evidence has been accumulating. A history of lower respiratory tract illness in early childhood has been shown to be associated with an increased incidence of respiratory symptoms and impaired ventilatory function in later childhood and early adult life. ${ }^{1-5}$ Many children with a history of recurrent wheezing become symptom free but respond abnormally to exercise 